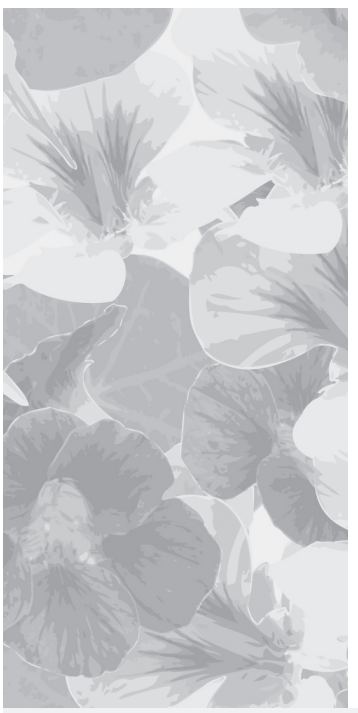

\title{
Co lekarze estetologii i kosmetolodzy powinni wiedzieć o roli racjonalnego żywienia w profilaktyce chorób nowotworowych
}

\section{What aesthetology physicians and cosmetologists should know about rational nutrition in the prevention of cancers}

\author{
Małgorzata Schlegel-Zawadzka \\ Zakład Żywienia Człowieka, Instytut Zdrowia Publicznego, Wydział Nauk o Zdrowiu, \\ Uniwersytet Jagielloński Collegium Medicum, Kraków \\ Estetol Med Kosmetol 2012; 2(2): 39-43 \\ DOI: http://dx.doi.org/10.14320/EMK.2012.008
}

\section{Streszczenie}

W pracy omówiono aktualne wytyczne Światowej Fundacji Badań nad Rakiem na temat zasad prawidłowego żywienia w profilaktyce nowotworów. Poszczególne zalecenia dietetyczne zostały przedstawione w formie zachęt skierowanych do indywidualnych osób, osadzonych w kontekście populacyjnych celów polityki zdrowotnej.

Stowa kluczowe: nowotwory, profilaktyka, żywienie

\section{Abstract}

This is an overview of the recommendations for proper nutrition in the prevention of cancers recently published by the World Cancer Research Fund. Particular nutritional recommendations are presented in the form of appeals directed to individual persons, put against the background of population goals of health policy.

Keywords: cancer, prevention, nutrition

Copyright @ 2012 the Authors (text) and Radostaw Śpiewak (layout \& journal compilation). All rights reserved.

W bibliograficznej bazie PubMed można znaleźć 16 publikacji odpowiadających na pytanie zadane w tytule [1-16]. Dodanie słowa kluczowego „,nutrition” zawęża efekt wyszukiwania do jednej publikacji [5]. Zidentyfikowane prace koncentrują się w zasadzie na trzech problemach: a) udziału kosmetologów w programach prozdrowotnych w społecznościach afro-amerykańskich, b) występowania nowotworów w grupie kobiet pracujących w gabinetach kosmetologicznych, oraz c) wiedzy na temat nowotworów skóry.

Kwestia programów prozdrowotnych z udziałem kosmetologów została szczegółowo omówiona w artykule, który można znaleźć w bieżącym numerze Estetologii Medycznej i Kosmetologii [17]. Wśród czynników ryzyka związanych z występowaniem nowotworów w grupie zawodowej kosmetologów najczęściej wskazuje się na palenie papierosów, ryzykowne zachowania seksualne oraz narażenie na substancje chemiczne o działaniu mutagennym. Brak jest natomiast prac analizujących zagrożenia zdrowotne związane z nieprawidłowymi zachowaniami żywieniowymi i brakiem aktywności fizycznej w tej grupie zawodowej.

W podsumowaniu projektu World Cancer Research Fund można znaleźć zarówno informacje o czynnikach ryzyka, jak i wskazówki na temat zapobiegania nowotworom [18]. Czynniki wpływające na ryzyko powstania nowotworu autorzy opracowania dzielą na globalne, narodowe, lokalne i te odnoszące się do indywidualnych jednostek. Czynniki ryzyka przyporządkowuje się do uwarunkowań środowiskowych, ekonomicznych oraz społecznych. Przedstawiono ponadto zalecenia profilaktyczne uwzględniające cele dla zdrowia publicznego i rekomendacje dla każdego człowieka indywidualnie, wraz z analizą ich dostępności, przystępności i akceptowalności. Panel ekspertów World Cancer Research Fund wyróżnił cztery poziomy wiarygodności danych na temat skuteczności metod prewencji nowotworów. Za przekonywująco dowiedzione uznano korzystne efekty karmienia piersią i aktywności fizycznej. Jako prawdopodobne wymieniono ponadto spożywanie żywności zawierającej błonnik pokarmowy, kwas foliowy, selen, likopen oraz jedzenie owoców. Z drugiej strony za prawdopodobne lub potwierdzone czynniki ryzyka nowotworów uznaje się aflatoksyny, czerwone mięso, przetwory mięsne, ryby solone na sposób kantoński, nadmierne spożycie soli, arsen w wodzie do picia, alkohol i napoje alkoholowe, nadmierne stosowanie beta-karotenu jako suplementu (nowotwór płuc), dietę bogatą w wapń (rak prostaty) oraz otyłość, w tym szczególnie otyłość brzuszną. 
Raport Food, nutrition, physical activity, and the prevention of cancer: A global perspective podaje 8 zaleceń ogólnych i 2 zalecenia specjalne, które powinny stanowić podstawę działań na rzecz obniżenia częstości nowotworów na świecie. Poniżej przedstawiono wytyczne w kolejności ustalonej przez panel ekspertów.

\section{Ottuszczenie ciała, otyłość}

Bądź tak szczupły, jak jest to możliwe w zakresie prawidłowego poziomu masy ciała ${ }^{1}$.

\section{Cele populacyjne}

Wartość mediany współczynnika masy ciała (BMI) ma wynosić pomiędzy 21 i 23, zależnie od normalnego prawidłowego zakresu dla różnych populacji ${ }^{2}$. Procent osób $\mathrm{z}$ nadwagą lub otyłością $\mathrm{w}$ populacji nie może być wyższy niż obecnie, ale pożądane jest jego obniżenie w perspektywie 10 lat.

\section{Zalecenia indywidualne}

Zapewnij, aby przez okres dzieciństwa i nastoletniości masa ciała zmierzała w kierunku dolnych wartości zakresu prawidłowego BMI dla 21-latków³ ${ }^{3}$ Utrzymuj masę ciała w zakresie normy dla 21 roku życia. Unikaj przytycia i pogrubienia fałdów skórno-tłuszczowych w ciągu całego dorosłego życia.

\section{Komentarze}

${ }^{1}$ Prawidłowe zakresy ustalane są przez narodowe zespoły ekspertów lub przez WHO.

${ }^{2}$ Celem jest zmniejszenie odsetka populacji poza zakresem normy.

${ }^{3}$ Pożądany jest taki przyrost wzrostu i masy ciała przez okres dzieciństwa, który prowadzi do dolnych zakresów normalnego BMI w okresie dorosłości, zgodnie z normami publikowanymi przez International Obesity Task Force i referencyjnymi siatkami rozwoju WHO.

\section{Aktywność fizyczna}

Bądź aktywny fizycznie, ruch powinien być ważną częścią Twoich codziennych czynności życiowych.

\section{Cele populacyjne}

Odsetek osób o siedzącym trybie życia ${ }^{1}$ powinien zmniejszać się o połowę co 10 lat. Średni poziom wskaźnika aktywności fizycznej (PAL) ${ }^{2}$ powinien być wyższy niż 1,63.

\section{Zalecenia indywidualne}

Bądź umiarkowanie aktywny fizycznie, co odpowiada szybkiemu marszowi przez co najmniej 30 minut dziennie. Gdy twoja sprawność się polepszy, dąż do przeznaczenia 60 minut lub więcej na umiarkowaną lub intensywną aktywność fizyczną codziennie ${ }^{3,4}$. Ogranicz siedzący tryb życia, czyli np. oglądanie telewizji.

\section{Komentarze}

'Określenie „siedzący tryb życia” odnosi się do PAL na poziomie 1,4 lub mniej.

${ }^{2}$ PAL (Physical Activity Level, Poziom Aktywności Fizycznej) jest miarą średniego nasilenia codziennej aktywności fizycznej. PAL jest obliczany przez podzielenie całkowitego wydatku energetycznego przez wartość podstawowej przemiany materii w danym okresie. ${ }^{3}$ Można w to włączyć pracę zawodową, transport, prace domowe lub aktywność w czasie wolnym.

${ }^{4}$ Długotrwała lub intensywna aktywność fizyczna jest korzystniejsza.

\section{III. Żywność i napoje powodujące przyrost masy ciata}

Ogranicz konsumpcję żywności wysokoenergetycznej ${ }^{1}$. Unikaj słodzonych napojów ${ }^{2}$.

\section{Cele populacyjne}

Średnia wartość gęstości energetycznej diety ${ }^{3}$ powinna się obniżyć do $125 \mathrm{kcal} / 100 \mathrm{~g}$. Populacja ludzi pijących napoje z zawartością cukru² powinna obniżać się o połowę co 10 lat.

\section{Zalecenia indywidualne}

Konsumuj rzadziej żywność o wysokiej gęstości energetycznej ${ }^{1,4}$. Unikaj słodzonych napojów ${ }^{2}$. Ograniczaj konsumpcję lub nie jedz wcale produktów z kategorii ,fast food"s.

\section{Komentarze}

${ }^{1}$ Żywność o wysokiej gęstości energetycznej jest definiowana jako przekraczająca wartości 225-275 $\mathrm{kcal} / 100 \mathrm{~g}$.

${ }^{2}$ Dotyczy to głównie napojów z dodatkiem cukru. Spożycie soków owocowych również powinno być ograniczone.

${ }^{3} \mathrm{Nie}$ dotyczy napojów.

${ }^{4}$ Ogranicz przetworzoną żywność o dużej gęstości (patrz również zalecenie IV). Nieprzetworzona żywność wysokoenergetyczna, taka jak orzechy lub nasiona, nie wpływa na przyrost masy ciała jeśli jest konsumowana jako część typowej diety i podobnie jak wiele olejów roślinnych jest dobrym źródłem składników odżywczych.

${ }^{5}$ Określenie ,fast food” odnosi się do gotowej żywności, która zwykle ma wysoką gęstość energetyczną i często serwowana jest w dużych porcjach.

\section{IV. Żywność pochodzenia roślinnego}

Jedz głównie żywność pochodzenia roślinnego. 


\section{Cele populacyjne}

Średnia konsumpcja warzyw i owoców nie zawierających błonnika rozpuszczalnego (skrobi) ${ }^{1}$ powinna wynosić przynajmniej $600 \mathrm{~g}$ dziennie ${ }^{2}$. Niskoprzetworzone produkty zbożowe (nasiona) lub rośliny strączkowe i inne naturalne źródła błonnika powinny mieć udział w żywieniu populacji nieskrobiowymi polisacharydami przynajmniej na poziomie $25 \mathrm{~g}$ dziennie.

\section{Zalecenia indywidualne}

Jedz przynajmniej 5 porcji (co najmniej 400 g) różnych warzyw nie zawierających znacznych ilości skrobi oraz owoców każdego dnia. Spożywaj niskoprzetworzone produkty zbożowe lub rośliny strączkowe w każdym posiłku3 ${ }^{3}$. Ogranicz żywność zawierającą cukry proste. Ludzie konsumujący jako główne źródło energii korzeniowe rośliny skrobiowe lub bulwy ${ }^{4}$ również powinni zapewnić sobie spożycie odpowiedniej ilości warzyw, owoców i roślin strączkowych o niskiej zawartości skrobi.

\section{Komentarze}

${ }^{1}$ Najłatwiej jest przygotować takie posiłki z różnych ilości różnokolorowych nieskrobiowych warzyw i owoców (czerwonych, zielonych, żółtych, białych, fioletowych i pomarańczowych) oraz na bazie pomidorów i warzyw cebulowych (np. czosnek).

${ }^{2}$ Niskoprzetworzone produkty zbożowe (nasiona) lub rośliny strączkowe powinny mieć udział wśród produktów nieskrobiowych w średniej ilości co najmniej $25 \mathrm{~g}$ dzienne.

${ }^{3}$ Ten typ żywności ma niską gęstość energetyczną i sprzyja utrzymaniu prawidłowej masy ciała.

${ }^{4}$ Na przykład ludność Afryki, Ameryki Łacińskiej oraz regionu Azji i Pacyfiku.

\section{V. Żywność pochodzenia zwierzęcego}

Ogranicz spożycie czerwonego mięsa ${ }^{1}$ i unikaj przetworów mięsnych ${ }^{2}$.

\section{Cele populacyjne}

Średnie spożycie czerwonego mięsa nie powinno przekraczać 300 g na tydzień.

\section{Zalecenia indywidualne}

Ludzie, którzy jedzą czerwone mięso ${ }^{1}$ powinni konsumować go mniej niż 500 g na tydzień.

\section{Komentarze}

'Termin „czerwone mięso” odnosi się do wołowiny, wieprzowiny, jagnięciny i mięsa kóz domowych oraz ich przetworów.

2,Przetwory mięsne” to mięsa konserwowane przez odymianie, wędzenie, solenie lub dodanie chemicznych środków konserwujących oraz wyroby z takich mięs.

\section{Napoje alkoholowe}

Ogranicz spożycie napojów alkoholowych ${ }^{1}$.

\section{Cele populacyjne}

Ograniczenie populacji osób pijących więcej niż zalecane limity o jedną trzecią w ciągu każdych 10 lat.

\section{Zalecenia indywidualne}

Jeśli pijesz napoje alkoholowe, ogranicz się do maksymalnie 2 drinków ${ }^{2}$ dziennie w przypadku mężczyzny i jednego drinka dziennie w przypadku kobiety ${ }^{3}$.

\section{Komentarze}

${ }^{1}$ Te rekomendacje uwzględniają możliwy efekt ochronny alkoholu przed chorobą niedokrwienną serca.

${ }^{2}$ Jeden „drink” zawiera około 10-15 g etanolu.

${ }^{3}$ Kobiety w ciąży oraz dzieci nie powinny pić napojów alkoholowych.

\section{Konserwowanie, przetwarzanie i przygo- towywanie}

Ogranicz spożycie soli ${ }^{1}$. Nie jedz spleśniałych zbóż i roślin strączkowych.

\section{Cele populacyjne}

Średnia konsumpcja soli kuchennej ze wszystkich źródeł powinna być mniejsza niż $5 \mathrm{~g}$ (2 g sodu) dziennie. Odsetek populacji konsumującej więcej niż $6 \mathrm{~g}$ soli (2,4 g sodu) dziennie powinien zmniejszać się o połowę co 10 lat. Należy minimalizować narażenie na aflatoksyny z zapleśniałych ziaren zbóż lub roślin strączkowych.

\section{Zalecenia indywidualne}

Unikaj słonej, solonej lub konserwowanej solą żywności; konserwuj żywność bez stosowania soli1 ${ }^{1}$. Ogranicz konsumpcję żywności przetworzonej z dodatkiem soli, tak aby zapewnić, że jesz jej mniej niż 6 g (2,4 g sodu) dziennie. Nie jedz zapleśniałych produktów zbożowych lub roślin strączkowych.

\section{Komentarze}

${ }^{1}$ Metodami konserwowania żywności, które nie wymagają dodawania soli są chłodzenie, zamrażanie, suszenie, butelkowanie, fermentacja, zamykanie w konserwach.

\section{Suplementy diety}

Zmierzaj do pokrycia zapotrzebowania na składniki odżywcze z samej diety ${ }^{1}$.

\section{Cele populacyjne}

Maksymalne zwiększenie populacji osiągającej pokrycie bieżącego zapotrzebowania na składniki odżywcze bez suplementów diety. 


\section{Zalecenia indywidualne}

Suplementy diety nie są rekomendowane w zapobieganiu nowotworom.

\section{Komentarze}

${ }^{1}$ Nie zawsze jest to możliwe. W niektórych stanach chorobowych lub gdy występują niedobory żywieniowe, przyjmowanie suplementów może być korzystne.

\section{Zalecenie specjalne 1: Karmienie piersią}

Karmienie piersią chroni zarówno matkę jak i dziecko.

\section{Cele populacyjne}

Maksymalne zwiększenie liczby matek karmiących swoje dzieci wyłącznie piersią ${ }^{1}$ przez pierwszych sześć miesięcy życia.

\section{Zalecenia indywidualne}

Karm niemowlę wyłącznie piersią ${ }^{1}$ do szóstego miesiąca życia, a dalej kontynuuj karmienie piersią łącznie z żywieniem uzupełniającym².

\section{Komentarze}

"Wyłącznie” oznacza tylko mleko kobiece bez żadnych innych produktów lub napojów, włączając w to wodę. ${ }^{2} Z$ godnie ze Światową Strategią Żywienia Niemowląt i Małych Dzieci ONZ.

Zalecenie specjalne 2: Osoby, które mają zdiagnozowany nowotwór lub zostały wyleczone z choroby nowotworowej ${ }^{1}$

\section{Zalecenia indywidualne}

Postępuj zgodnie z rekomendacjami na temat zapobiegania nowotworom ${ }^{2}$.

\section{Rekomendacje}

Wszyscy pacjenci ${ }^{3}$ powinni otrzymać opiekę żywieniową od odpowiednio wykształconego profesjonalisty (dietetyka). W przypadku braku takiej możliwości, dążyć trzeba do postępowania zgodnego z rekomendacjami dla zdrowej diety, prawidłowej masy ciała i aktywności fizycznej². Po zakończeniu leczenia przeciwnowotworowego należy postępować zgodnie z zaleceniami dla zapobiegania nowotworom. Należy bezwzględnie zaprzestać palenia oraz żucia tytoniu.

\section{Komentarze}

${ }^{1}$ Ludzie, którzy żyją z rozpoznaniem nowotworu, włączając tych, którzy wyzdrowieli.

${ }^{2} \mathrm{Nie}$ dotyczy chorych $\mathrm{w}$ trakcie aktywnej terapii nowotworu.

${ }^{3}$ Dotyczy wszystkich przed i po aktywnej terapii nowotworu.

Omówiony raport Food, nutrition, physical activity, and the prevention of cancer: A global perspective przytacza dowody naukowe potwierdzające, że utrzymywanie prawidłowej masy ciała dzięki diecie i aktywności fizycznej może ograniczyć ryzyko nawrotu nowotworu [18].

\section{Piśmiennictwo}

1. Bailey EE, Marghoob AA, Orengo IF, Testa MA, White VR, Geller AC: Skin cancer knowledge, attitudes, and behaviors in the salon: a survey of working hair professionals in Houston, Texas. Arch Dermatol 2011;147(10):1159-65.

2. Goldberg MS, Labreche F: Occupational risk factors for female breast cancer: a review. Occup Environ Med 1996;53(3):145-56.

3. Guidotti S, Wright WE, Peters JM: Multiple myeloma in cosmetologists. Am J Ind Med 1982;3(2):169-71.

4. Habel LA, Stanford JL, Vaughan TL, Rossing MA, Voigt LF, Weiss NS, Daling JR: Occupation and breast cancer risk in middle-aged women. J Occup Environ Med 1995;7(3):349-56.

5. Leigh JP: Occupations, cigarette smoking, and lung cancer in the epidemiological follow-up to the NHANES I and the California Occupational Mortality Study. Bull N Y Acad Med 1996;73(2):370-97.

6. Linnan LA, Ferguson YO, Wasilewski Y, Lee AM, Yang J, Solomon F, Katz M: Using community-based participatory research methods to reach women with health messages: results from the North Carolina BEAUTY and Health Pilot Project. Health Promot Pract 2005;6(2):164-73.

7. Ng AT, Chang AL, Cockburn M, Peng DH: A simple intervention to reinforce awareness of tanning bed use and skin cancer in non-medical skin care professionals in Southern California. Int J Dermatol 2012;51(11):1307-12.

8. Osorio AM, Bernstein L, Garabrant DH, Peters JM: Investigation of lung cancer among female cosmetologists. J Occup Med 1986;28(4):291-5.

9. Quach T, Doan-Billing PA, Layefsky M, Nelson D, Nguyen KD, Okahara L, Tran AN, Von Behren J, Reynolds P: Cancer incidence in female cosmetologists and manicurists in California, 1988-2005. Am J Epidemiol 2010;172(6):691-9.

10. Robinson CF, Walker JT: Cancer mortality among women employed in fast-growing U.S. occupations. Am J Ind Med 1999;36(1):186-92.

11. Sadler GR, Ko CM, Cohn JA, White M, Weldon RN, Wu P: Breast cancer knowledge, attitudes, and screening behaviors among African American women: The Black cosmetologists promoting health program. BMC Public Health 200717;7:57.

12. Sadler GR, Ko CM, Wu P, Alisangco J, Castañeda SF, Kelly C: A cluster randomized controlled trial to increase breast cancer screening among African American women: The black cosmetologists promoting health program. J Natl Med Assoc 2011;103(8):735-45.

13. Sadler GR, Meyer MW, Ko CM, Butcher C, Lee S, Neal T, Reed L, Veals AE, Gilpin EA: Black cosmetologists promote diabetes awareness and screening among African American women. Diabetes Educ 2004;30(4):676-85.

14. Sadler GR, Thomas AG, Gebrekristos B, Dhanjal SK, Mugo J: Black cosmetologists promoting health program: pilot study outcomes. J Cancer Educ 2000;15(1):33-7. 
15. Spinelli JJ, Gallagher RP, Band PR, Threlfall WJ: Multiple myeloma, leukemia, and cancer of the ovary in cosmetologists and hairdressers. Am J Ind Med 1984;6(2):97-102.

16. Teta MJ, Walrath J, Meigs JW, Flannery JT: Cancer incidence among cosmetologists. J Natl Cancer Inst 1984;72(5):1051-7.

17. Plichta D, Śpiewak R: Edukacja zdrowotna i promocja zdrowia w gabinecie kosmetologicznym. Estetol Med Kosmetol 2012;2(2): 44-9.

18. World Cancer Research Fund, American Institute for Cancer Research. Policy and action for cancer prevention. Food, nutrition and physical activity: A global perspective. AICR, Washington DC 2009.

\section{Finansowanie i konflikt interesów}

Autorka deklaruje niewystępowanie konfliktu interesów w odniesieniu do treści zawartych w niniejszej pracy.

\section{Adres do korespondencji}

prof. Małgorzata Schlegel-Zawadzka

Zakład Żywienia Człowieka UJ CM

ul. Grzegórzecka 20, 31-531 Kraków

Email:mfzawadz@cyf-kr.edu.pl

Data złożenia: 28.04.2012

Data akceptacji: 30.04 .2012

Data aktualizacji: 30.11.2012

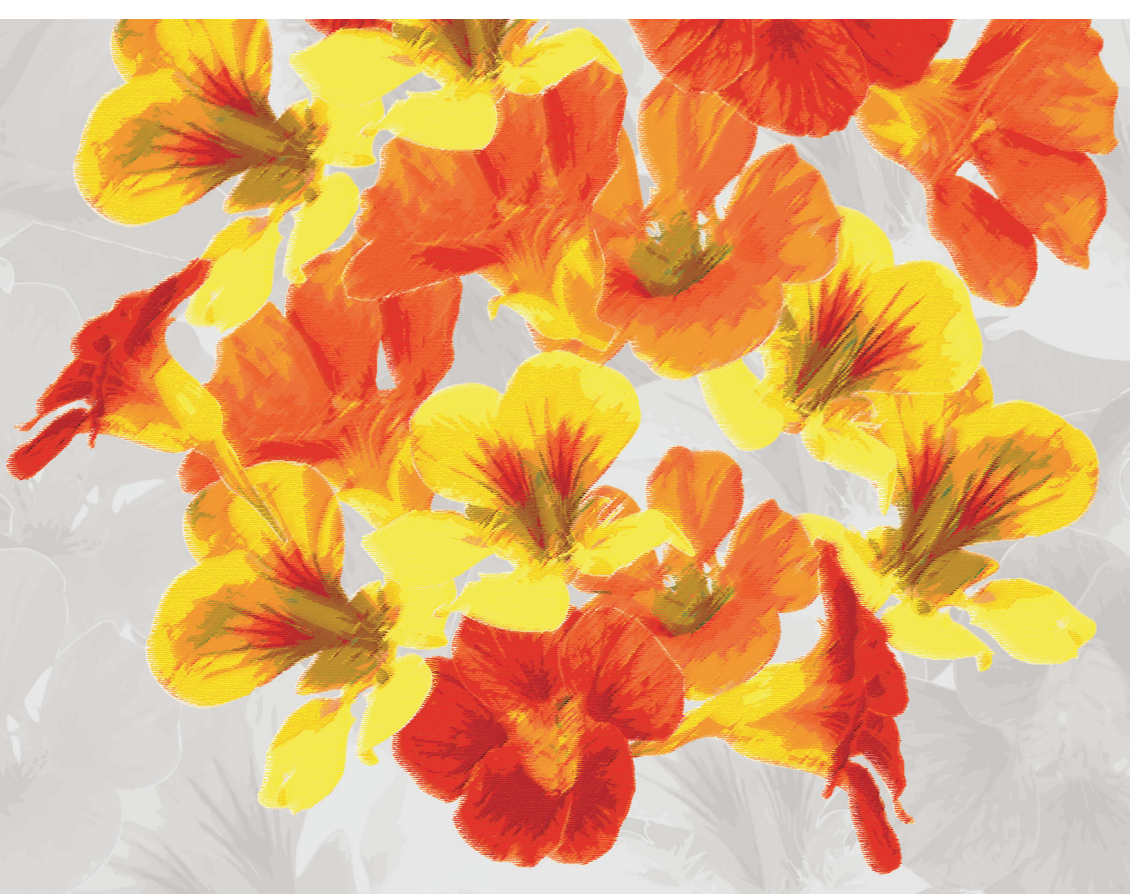

estetologia med ycz n a kosmetologia

\section{Pierwsze czasopismo} interdyscyplinarne z zakresu medycyny estetycznej kosmetologii i nauk pokrewnych Open Access!

zobacz na www.estetologia.pl 